\title{
Awareness of different forms of child abuse among Beni Suef University students: descriptive survey
}

\author{
Nermeen N. Welson ${ }^{1 *}$ and Yasmen A. Mohamed ${ }^{2}$
}

\begin{abstract}
Background: Child abuse is a worldwide phenomenon that can cause intense long-term aftereffects.

Aim: To evaluate the awareness of Beni Suef University students about different forms of child abuse as well as the size, causes, and complications of this problem in our society and determine the prevalence of physical child abuse.

Methods: The study included 1688 students from health science and non-health science colleges of Beni Suef University, Egypt. The study participants were asked to answer a questionnaire of two parts. The first part included questions about demographic data and personal experience of child abuse, and the second part included questions about opinions of participants on child abuse to assess their awareness and if there was any difference in the level of awareness between students of health science colleges and those of non-health science colleges.

Results: Health science college students were more life satisfied and felt more loved. Only $28.91 \%$ of the included students were not exposed to child abuse, while $12.59 \%$ of them suffered from wounds or fractures as a result of the abuse they were exposed to. About one third of the students thought that the commonest form of child abuse is verbal punishment such as threatening or humiliation and that the age at the greatest risk for abuse was the primary school age. About $68.36 \%$ of students thought that sexual abuse is a huge problem in our society. Only $21.56 \%$ of students disapproved child corporal punishment. More than half of the students stated that the most dangerous complication of child abuse is psychological problems such as depression. Most of the included students would talk to the child's parents and advise them if they saw a case of abuse, while the least would call the police. Only half of the students disapproved female genital mutilation (FGM). The strongest predictive factors for FGM approval were rural residence and male sex. Students mainly thought that FGM is a social habit that is carried out for ethical causes. About half of the students approved legal punishment by the court for FGM performers.

Conclusion: A significant proportion of the students experienced physical child abuse which left no injuries in most cases; males and first academic year students show more exposure to abuse. Moreover, most of the students think that child corporal punishment can be allowed although about half of them think that the most dangerous aftereffect of child abuse is psychological problems. Lack of reporting the exposure to child abuse is explained by the largest percentage of students to be due to lack of awareness. Rural resident males show more approval of female genital mutilation. A significant lack of awareness about FGM complications is observed in both groups (the health science and non-health science college groups) and the opinions of both groups are very close.
\end{abstract}

Keywords: Child abuse, Negligence, Prevalence, Questionnaire, Female genital mutilation

\footnotetext{
*Correspondence: nermeennemr@yahoo.com

${ }^{1}$ Forensic Medicine and Clinical Toxicology Department, Faculty of Medicine,

Beni Suef University, Beni Suef, Egypt

Full list of author information is available at the end of the article
} 


\section{Key points}

1. About two thirds of the students are exposed to physical child abuse. Males and first academic year students are more exposed to corporal punishment.

2. Child abuse is not related to parents' education, residence, faculty, or family condition and this finding can indicate that child abuse is still a common phenomenon in the society.

3. There is obvious cultural and social acceptance of physical punishment as a method of behaving children as about three fourths of the students accepted it.

4. Most of the students will talk to the parents if they suspect a case of child abuse and they perceive that there is a lack of awareness in the society.

5. Only half of the students (mainly females) disapprove FGM and most of them see that it is a social custom held for ethical causes (for fear of misconduct).

6. The most important predictive factors for FGM approval are the rural residence and the male sex.

\section{Background}

Child abuse is a worldwide problem explained by the WHO as "any physical or emotional ill-treatment, sexual abuse, neglect, or other exploitation the child is exposed to by a responsible guardian, causing direct or indirect harm to his life, health, or development." Thus, there are four main types of child maltreatment and abuse: physical abuse, sexual abuse, psychological abuse, and neglect (WHO 1999).

Physical child abuse includes corporal punishment as slapping children with the hand or hitting them with implements including stick, belt, shoe, etc. Other examples of physical abuse are biting, pinching, pulling hair, uncomfortable positioning, burning, and forced ingestion. This violence may cause many physical and psychological effects such as re-victimization, homelessness, personality disorders, depression, anxiety, aggression, post-traumatic stress disorder, suicidal attempts, eating disorders, and substance abuse (Kelly-Irving et al. 2013). In addition, child abuse can cause serious and potentially fatal complications such as shaken baby syndrome which results in intracranial hemorrhage, increased intracranial pressure, neurological damage, spinal cord injury, rib fractures, or visceral injury (Morad et al. 2010). Sever injuries cause complications including death where the most common causes of death are reported to be head and abdominal injuries. Child abuse occurs in many parts of the world. The World Health Organization (WHO) indicated that there were 57,000 deaths caused by child abuse in 2000 globally (Alexander et al. 2001).
Sexual abuse includes a child's involvement in a sexual act for physical or financial gain, such as child genital exposure, viewing or sexual contact with a child, and child pornography. Psychological abuse is the most common and challenging type of child abuse. It includes screaming, stigmatization, threatening, coarse attitude, inattention, humiliation, excessive criticism, destruction of personal belongings, and inappropriate or excessive demands (Theoklitou et al. 2012).

There are six sub-types of child neglect:

1. Supervisory neglect: absence of adult supervision capable of causing physical harm, sexual harassment, or criminal conduct

2. Physical neglect: inability to provide basic physical needs such as a peaceful and tidy house

3. Health neglect: insufficient care of child health

4. Emotional neglect: lack of caring and support

5. Academic neglect: lack of school system participation

6. Abandonment: leaving a child alone without an adult supervision for a long time. Neglected children can find future difficulties in trusting people or forming relationships due to the preexperienced lack of attachment (Golden and Prather 2009).

Female genital mutilation (FGM) includes any injury or cutting off female genital organs for non-therapeutic purposes. It is performed in the Middle East, some African countries, and parts of Asia. The most vulnerable age groups to FGM are infancy and childhood till the age of puberty. There are four types of FGM; the most common type practiced in Egypt is type 1, also known as clitoridectomy, which includes partial or total excision of the clitoris or the prepuce (Rasheed et al. 2011). Type 3 , known as infibulation, is the most radical type of FGM, and it is commonly practiced in northeast Africa, especially Somalia and Djibouti. Studies showed that FGM is more prevalent in rural areas due to lack of knowledge and low socioeconomic status but it is less common among educated and wealthier families. Moreover, some people suggest that FGM is performed because of religious causes; however, this belief is doubtful and cannot be proven (Cappa et al. 2013).

FGM not only has no known useful healthy effects but also has severe and long-term complications including recurrent infections, chronic pain, and cyst formation as well as psychological and sexual problems. It also affects pregnancy (Reisel and Creighton 2015).

The child law was ratified by Egyptian authority in 1996 and amendments were made in 2008. This law includes the rights of children in medical care, education, and social utilities. Furthermore, the practice of FGM 
has been criminalized since a 12-year old girl died during FGM by a physician in an illegal clinic in 2007 (Michael 2007).

According to a US survey study in 1995, the physical child abuse rate was 49/1000 (Straus and Gelles 1998). In another Korean study, $45 \%$ of parents reported using corporal punishment of their children and two thirds of them admitted whipping their children (Hahm and Guterman 2001).

Moreover, an Egyptian survey showed that $63 \%$ of children were exposed to physical abuse and $26 \%$ of those abused children had severe injuries as fractures and permanent disabilities (Youssef et al. 1998). Another Saudi Arabian study carried out on 186 abused children showed that the victims were mainly males from largesized families and with illiterate parents (Elsaied and Alsehly 2017).

The current study aims to evaluate the awareness of Beni Suef University students about different forms of child abuse as well as the size, causes, and complications of this problem in our society and determine the prevalence of physical child abuse.

\section{Materials and methods}

\section{Study design}

The present study was conducted in April, June, and July 2018 among Beni Suef University students of the academic year 2017/ 2018 which started in September 2017 and ended in July 2018. The study was approved by the institutional research ethical committee. One college was covered per day. We visited the students in their lecture rooms in between the academic sessions to assess the largest possible number of students without disruption of their lectures. The aim and methods of the study were explained to the students; then, the questionnaires were distributed. The students were asked to write their college and grade then answer the multiplechoice questions without sharing the answers or looking at neighboring questionnaires. The students were confirmed that their answers would be used only for health science research and no names were required. The questionnaires were answered within $30 \mathrm{~min}$ then collected.

\section{Sampling design}

In Egypt, there are two main groups of colleges which are different in the field of study: health science colleges and non-health science colleges. The health science colleges (specialized in health care) involve students who are specialized in biology and human health studies since high school such as the Faculty of Sciences, Faculty of Medicine, Faculty of Dentistry, Faculty of Veterinary Medicine, and Faculty of Physical Therapy, while nonhealth science colleges (not specialized in health care) involve students who are specialized in arts, economic, and social studies with less knowledge about biology or human health such as the Faculty of Commerce, Faculty of Arts, Faculty of Education, and Faculty of Law. The Beni Suef Governorate lies in Upper Egypt where social attitudes are more conservative. The university students are mainly the natives of the region. Beni Suef University has 35 main colleges and institutes with a population size of about 67,000 students. The largest four health science colleges and the largest four non-health science colleges were chosen. Two thousand students were planned to join this study. Informed consent was obtained and the students who desired to join the study filled the questionnaire. Partially filled questionnaires were included in the study but blank returned questionnaires were excluded so the final number of participants was 1688 students; the response rate about $84 \%$.

\section{Questionnaire}

The investigators were guided by the survey of North Dakota State University (Rathge et al. 2005) to choose socially and culturally accepted questions for the used questionnaire. The questionnaire was prepared in Arabic and English, examined by 3 experts, and tested on 15 students who were not included in the study for modifications and validation. It was classified into two main parts; the first part included questions about demographic data and personal experience such as faculty, grade, sex, residence, family data (father's education, mother's education, and condition of the family such as presence of both parents, death of one or both parents, or divorce) and domestic abuse personal experience (domestic life satisfaction, feeling of parents' love and support, previous exposure to physical abuse by one or both parents, and if this physical abuse resulted in bruises or fractures). The question about exposure to physical abuse and if it caused bruises or fractures was used to evaluate how serious the corporal punishment was. Moreover, the question about domestic life satisfaction was used to know how the students evaluate their life as a whole rather than situational feeling.

The second part of the questionnaire included questions about the students' opinions and personal visions and consisted of other four categories of questions. The first category was about the problem risk factors and possible causes. Asked questions were about the commonest form of child abuse, approval of mother's work before her children's enrollment in school, the father's role in raising children in comparison with the mother's role, the age group at the greatest risk for exposure to physical abuse, child labor, and the suitable age group that children become dependent and their mother can leave them alone at home without adult supervision for a few hours.

The second category of questions evaluated the awareness of students about the child sexual abuse problem. 
Asked questions were about the size of the problem in our society, the age at the greatest risk for sexual abuse, who the abuser can be, and the importance of sexual education for school students. The last question choices were important since primary school stage, important since preparatory or secondary school stage (the children in their early life are not supposed to learn about sexual issues because of social conservatism), not important and only awareness campaigns against sexual harassment are needed, and not important at all.

The third category of questions was about the complications of child abuse in general and what to do if you suspect abuse. The questions included were if corporal punishment can be allowed in raising children, the most dangerous child abuse complication on the long run, what to do if you suspect abuse, and why there is a lack of reporting of this problem. The proposed complications were depression and other psychiatric problems, personality changes as riot or violence, education problems, and drug addiction. The proposed answers for the question of lack of reporting the problem were society's lack of information about how to report, lack of awareness about the problem's severity, lack of physical evidence to prove the assault, and no desire to interfere in others' affairs.

The last category of questions was for female genital mutilation (FGM) which is popular in our society and also known as female circumcision. The questions included were approval of FGM, its origin, aim, and effect on women's health, approval of legal punishment by the court for FGM performers, and its long-run effect on family life and pregnancy. The proposed causes of FGM origin in Egypt included religious commitment and social custom. The proposed answers for why FGM supporters perform it (FGM aims) included ethical reasons (for fear of misconduct), personal hygiene or cleanliness, and early puberty or maturation of the girl (Additional file 1).

Choosing more than one answer or no answer and writing another answer that was not included in the defined choices were considered to be missing data.

\section{Results}

This study included a total number of 1688 students from health science and non-health science colleges. Included health science colleges were the Faculty of Medicine, Faculty of Sciences, Faculty of Veterinary Medicine, and Faculty of Physiotherapy and the included nonhealth science colleges were the Faculty of Commerce, Faculty of Arts, Faculty of Education, and Faculty of Law. The students from non-health science colleges represented $56.2 \%$ of the study population, while those from health science colleges represented $43.8 \%$. The study included $60.3 \%$ females and $37.7 \%$ males. Missing data were $2 \%$.
Distribution of included students according to faculty, academic year, sex, and residence were summarized in (Table 1).

\section{Family data}

The level of father's education for the students of health science colleges was university education in $66.22 \%$, secondary school (high school) education in $22.7 \%$, and elementary education (primary and preparatory schools) in $6.22 \%$. There was a percentage of $4.86 \%$ representing missing data or not included choices in the questionnaire, mainly as an uneducated parent. Regarding nonhealth science college students, the percentages were $44.09 \%$ for secondary school education, $25.53 \%$ for university education, $22.57 \%$ for elementary education, and $7.81 \%$ for missing or other not appointed choices as uneducated parents. The difference between both groups in the father's level of education was statistically significant. The level of mother's education for health science college students was university education in $59.46 \%$, secondary school education in $22.34 \%$, elementary school education in $12.7 \%$, and missing data or other not included choices in $5.41 \%$. For non-health science college students, the percentages were $37.34 \%$ for secondary school education, $33.97 \%$ for elementary school education, $16.03 \%$ for university education, and $12.66 \%$

Table 1 Demographic characteristics of the study included students

\begin{tabular}{lll}
\hline & No. & Percent \\
\hline Faculty & & \\
Health science colleges & 740 & 43.8 \\
Non-health science colleges & 948 & 56.2 \\
Academic year & & \\
First year & 562 & 33.29 \\
Second year & 350 & 20.73 \\
Third year & 452 & 26.78 \\
Fourth year & 228 & 13.51 \\
Fifth year & \\
Sixth year** & 42 & 2.49 \\
Missing data & 14 & 0.83 \\
Sex & 40 & 2.37 \\
Male & & \\
Female & 636 & 37.7 \\
Missing data & 1018 & 60.3 \\
Residence & 34 & 2 \\
Village & & 52 \\
City & 878 & 42.5 \\
Missing data & 718 & \\
\hline
\end{tabular}

*Fifth year is present only in health science colleges

**Sixth year is present only in the Faculty of Medicine 
missing or other answers including uneducated parents and this difference was also statistically significant. The difference in family conditions between the two groups of students was not statistically significant (Table 2).

\section{Personal experience}

The students of health science colleges were more life satisfied and felt more loved than those of non-health science colleges. Two thirds of the students previously experienced physical child abuse; $12.5 \%$ of them had serious abuse that resulted in bruises, fractures, or wounds. No significant difference between the two groups was revealed regarding personal experience of physical child abuse (Table 2).

After the exclusion of missing data, exposure to physical child abuse was defined as frequent (always and often possibilities) and infrequent (rare and never possibilities). Exposure to child abuse was significantly associated with both sexes and the academic year where males and first academic year students were more exposed to physical child abuse. But it was not related to faculty, residence, parents' education level, or family condition (Table 3).

The beliefs and opinions of students regarding child abuse were collected in the other four categories (Table 4).

\section{Risk factors and possible causes}

The commonest form of child abuse according to the students' opinions was threating (37.68\%), followed by negligence $(28.67 \%)$, then beating $(25.83 \%)$, and finally sexual abuse $(6.52 \%)$ with missing data of $1.3 \%$. Generally and even with enough family income, most of the students approved the idea of mothers having jobs outside home before their children reach the age of school enrollment, while $27.61 \%$ disapproved this idea.

Regarding the father's role in rearing children, about half of the students perceived that it is equal to the mother's role, $26.78 \%$ said that it is less important, $21.33 \%$ said that it is more important than the mother's role, $2.25 \%$ said that fathers have no role at all, and there were $0.47 \%$ missing data. The age at the greatest risk for abuse was proposed to be the age of primary school (from 6 to 11 years) by most of the students (66.47\%) and the least exposed age was proposed to be the age of joining college ( $>17$ years) by $0.47 \%$ of the students.

The most suitable age in which children become independent and their mothers can leave them unattended alone at home for a few hours was proposed to be 7-9 years by $29.29 \%$ of the students, while a close percentage of students $(29.17 \%)$ suggested that age to be 10-12 years. Child labor was completely disapproved by $65.4 \%$ of students, while it was approved by a considerable percentage $(25 \%)$ if it is greatly needed and there was a statistically significant difference between the two groups of students. This may reflect other social problems as poverty or education dropout where the children can be the main source of family sustenance.

The statistically significant differences in opinions between the two groups of colleges was found in the points of early mother's work, father's role in rearing children, child labor, and age of leaving children alone unattended at home for a few hours.

\section{Child sexual abuse}

A statistically significant difference was revealed between both groups of students regarding their view of sexual abuse. Most of the students perceived that it is a widespread issue in the society, $27.84 \%$ said that it is a smallsized problem, $3.32 \%$ said that it is not a problem in the society at all, and there were $0.47 \%$ missing data or the students did not know.

The age at the greatest risk for sexual abuse was proposed to be the primary school age (6-11 years) by $32.23 \%$ of students, while the least age was suggested to be $<4$ years by $9.48 \%$ of students and there was also a statistically significant difference between the two groups regarding this.

Half of the students thought that sexual abusers are mainly strangers, $29.03 \%$ suggested that they are friends, and $17.42 \%$ suggested that they are family members. Regarding sexual education, $41.71 \%$ of the students saw that it is important only in the stage of preparatory or secondary school age, one third of the students thought that it is important from the primary school stage, $24.53 \%$ said it is not important and only awareness campaigns or general lectures are enough, and $2.37 \%$ chose that sexual education is not important at all. There was a statistically significant difference in opinions between the two groups.

\section{Child abuse complications and control}

Most of the students thought that mild corporal punishment can be allowed in children raising but only in big or repeated mistakes or with failure of other punishment methods (allowed within limits), $21.56 \%$ said that it cannot be allowed at all, while $3.67 \%$ said that it can be completely allowed.

Regarding the most dangerous complication that can be caused by child abuse, the probabilities were $54.03 \%$ for psychological problems (e.g., depression), 33.77\% for personality changes (e.g., riot or violence), $5.21 \%$ for education problems, and $4.86 \%$ for drug addiction. There were $2.13 \%$ missing data, do not know, or more than one choice.

Regarding the action taken if the participant suspects abuse, most of the students chose to talk with the 
Table 2 Distribution of included students according to family data and personal experience

\begin{tabular}{|c|c|c|c|c|c|c|}
\hline & \multicolumn{2}{|c|}{ Health science colleges } & \multicolumn{2}{|c|}{ Non-health science colleges } & \multicolumn{2}{|l|}{ Total } \\
\hline & No. & $\%$ & No. & $\%$ & No. & $\%$ \\
\hline \multicolumn{7}{|l|}{ Family data } \\
\hline \multicolumn{7}{|l|}{ Father education } \\
\hline Elementary education & 46 & 6.22 & 214 & 22.57 & 260 & 15.4 \\
\hline Secondary school & 168 & 22.7 & 418 & 44.09 & 586 & 34.72 \\
\hline University education & 490 & 66.22 & 242 & 25.53 & 732 & 43.36 \\
\hline Others or missing data & 36 & 4.86 & 74 & 7.81 & 110 & 6.52 \\
\hline$x^{2}=291$ & $P<0.01$ & & & & & \\
\hline \multicolumn{7}{|l|}{ Mother education } \\
\hline Elementary education & 94 & 12.7 & 322 & 33.97 & 416 & 24.46 \\
\hline Secondary school & 166 & 22.34 & 354 & 37.34 & 520 & 30.81 \\
\hline University education & 440 & 59.46 & 152 & 16.03 & 592 & 35.07 \\
\hline Others or missing data & 40 & 5.41 & 120 & 12.66 & 160 & 9.48 \\
\hline$x^{2}=350$ & $P<0.01$ & & & & & \\
\hline \multicolumn{7}{|l|}{ Family condition } \\
\hline Both parents & 594 & 80.27 & 784 & 82.7 & 1378 & 81.64 \\
\hline Death & 102 & 13.78 & 124 & 13.08 & 226 & 13.39 \\
\hline Divorce & 28 & 3.78 & 28 & 2.95 & 56 & 3.32 \\
\hline Missing data & 16 & 2.16 & 12 & 1.27 & 28 & 1.66 \\
\hline$x^{2}=3.33$ & $P=0.34$ & & & & & \\
\hline \multicolumn{7}{|c|}{ Child abuse personal experience } \\
\hline \multicolumn{7}{|l|}{ Life satisfaction } \\
\hline Satisfied & 303 & 81.89 & 644 & 67.93 & 1250 & 74.05 \\
\hline Not satisfied & 63 & 17.03 & 292 & 30.8 & 418 & 24.76 \\
\hline Missing data & 4 & 1.08 & 12 & 1.27 & 20 & 1.18 \\
\hline$x^{2}=42.9$ & $P<0.01$ & & & & & \\
\hline \multicolumn{7}{|l|}{ Feeling loved } \\
\hline Enough & 574 & 77.57 & 672 & 70.89 & 1246 & 73.82 \\
\hline Not enough & 122 & 16.49 & 226 & 23.84 & 348 & 20.62 \\
\hline Never been & 38 & 5.14 & 38 & 4.01 & 76 & 4.5 \\
\hline Missing data & 6 & 0.81 & 12 & 1.27 & 18 & 1.07 \\
\hline$x^{2}=15.39$ & $P<0.01$ & & & & & \\
\hline \multicolumn{7}{|l|}{ Previously abused } \\
\hline Always & 40 & 5.41 & 42 & 4.43 & 82 & 4.86 \\
\hline Often & 178 & 24.05 & 260 & 27.43 & 438 & 25.95 \\
\hline Rare & 314 & 42.43 & 356 & 37.55 & 670 & 39.69 \\
\hline Never & 202 & 27.3 & 286 & 30.17 & 488 & 28.91 \\
\hline Missing data & 6 & 0.81 & 4 & 0.42 & 10 & 0.59 \\
\hline$x^{2}=7.37$ & $P=0.117$ & & & & & \\
\hline \multicolumn{7}{|l|}{ Serious abuse } \\
\hline Yes & 94 & 12.7 & 118 & 12.45 & 212 & 12.59 \\
\hline No & 638 & 86.22 & 826 & 87.13 & 1464 & 86.73 \\
\hline Missing data & 8 & 1.08 & 4 & 0.42 & 12 & 0.71 \\
\hline$x^{2}=2.6$ & $P=0.27$ & & & & & \\
\hline
\end{tabular}


Table 3 Relation between exposure to physical child abuse and other studied data

\begin{tabular}{|c|c|c|c|c|c|}
\hline & Frequent exposure* & Infrequent or non-exposure ${ }^{* *}$ & Total & $x^{2}$ & $P$ \\
\hline \multicolumn{6}{|l|}{ Faculty } \\
\hline Health science & $218(29.7 \%)$ & $516(70.3 \%)$ & $734(43.74 \%)$ & 1 & 0.3 \\
\hline Non-health science & $302(32 \%)$ & $642(68 \%)$ & $944(56.26 \%)$ & & \\
\hline \multicolumn{6}{|l|}{ Year } \\
\hline 1 & $206(37.18 \%)$ & $348(62.82 \%)$ & $554(33 \%)$ & 25 & $<0.001$ \\
\hline 2 & 118 (34\%) & $230(66 \%)$ & $348(21.2 \%)$ & & \\
\hline 3 & $106(23.45 \%)$ & $346(76.55 \%)$ & $452(27 \%)$ & & \\
\hline 4 & $64(28 \%)$ & $164(71.93 \%)$ & $228(13 \%)$ & & \\
\hline 5 & $10(23.8 \%)$ & $32(76.2 \%)$ & $42(2.5 \%)$ & & \\
\hline 6 & $4(28.57 \%)$ & $10(71.43 \%)$ & $14(0.8 \%)$ & & \\
\hline Missing data & $12(30 \%)$ & $28(70 \%)$ & $40(2.4 \%)$ & & \\
\hline \multicolumn{6}{|l|}{ Sex } \\
\hline Male & $242(38.29 \%)$ & $390(61.71 \%)$ & $632(37.66 \%)$ & 32 & $<0.001$ \\
\hline Female & $262(25.89 \%)$ & $750(74.11 \%)$ & $1012(60.31 \%)$ & & \\
\hline Missing data & $16(47.06 \%)$ & $18(52.94 \%)$ & $34(2.3 \%)$ & & \\
\hline \multicolumn{6}{|l|}{ Family condition } \\
\hline Both & $434(31.5 \%)$ & $942(68.5 \%)$ & $1376(82 \%)$ & 2 & 0.5 \\
\hline Death & $64(\%)$ & $162(\%)$ & $226(13.5 \%)$ & & \\
\hline Divorce & $18(\%)$ & $38(\%)$ & $56(\% 3.3)$ & & \\
\hline Missing data & $4(\%)$ & $16(\%)$ & $20(1.2 \%)$ & & \\
\hline \multicolumn{6}{|l|}{ Father education } \\
\hline Precollege education & $247(52.69 \%)$ & $572(49.40 \%)$ & $846(50.42 \%)$ & 1.59 & 0.452 \\
\hline College education & $216(41.54 \%)$ & $512(44.21 \%)$ & $728(43.38 \%)$ & & \\
\hline Missed data (including illiterate) & $30(5.77 \%)$ & $74(6.39 \%)$ & $104(6.20 \%)$ & & \\
\hline \multicolumn{6}{|l|}{ Mother education } \\
\hline Precollege education & $284(54.62 \%)$ & $652(56.30 \%)$ & $936(55.78 \%)$ & 3.53 & 0.181 \\
\hline College education & $178(34.23 \%)$ & $410(35.41 \%)$ & $588(35.04 \%)$ & & \\
\hline Missed data (including illiterate) & $58(11.15 \%)$ & 96 (8.29\%) & $154(9.18 \%)$ & & \\
\hline \multicolumn{6}{|l|}{ Residence } \\
\hline City & $228(31.9 \%)$ & $486(68.1 \%)$ & $714(42.5 \%)$ & 1.8 & 0.4 \\
\hline Village & $260(25.89 \%)$ & $614(74.11 \%)$ & $874(52.1 \%)$ & & \\
\hline Missed data & 32 (\%) & $58(\%)$ & 90 (5.4\%) & & \\
\hline
\end{tabular}

*Frequent exposure $=$ always and often possibilities

**Infrequent exposure $=$ rare and never possibilities

parents, $8.65 \%$ chose to do nothing, and $7.7 \%$ chose to call the police.

Causes for lack of reporting abuse were proposed to be as follows: $42.18 \%$ of the students thought that the reason is lack of awareness, $31.64 \%$ saw that it is not appropriate to interfere in others' personal affairs, $17.65 \%$ chose lack of information about how to report abuse and about the concerned authority, and $6.16 \%$ chose lack of physical evidence to prove the abuse. There were $2.37 \%$ missing data. A significant difference in opinions between the two groups was found in all the four points; approval of corporal punishment, the most dangerous complication caused by child abuse, what to do if you suspect abuse, and the reason for lack of reporting abuse.

\section{FGM}

In the health science colleges group, $57.57 \%$ of the students disapproved FGM, 30.54\% chose do not know, and $11.89 \%$ approved it. The opinions in non-health science colleges showed a slight difference in which $51.27 \%$ disapproved FGM, 31.01\% do not know, and $17.3 \%$ approved it. There were $0.42 \%$ missing data. The difference between the two groups regarding this point was statistically significant. 
Table 4 Students' opinions and attitudes

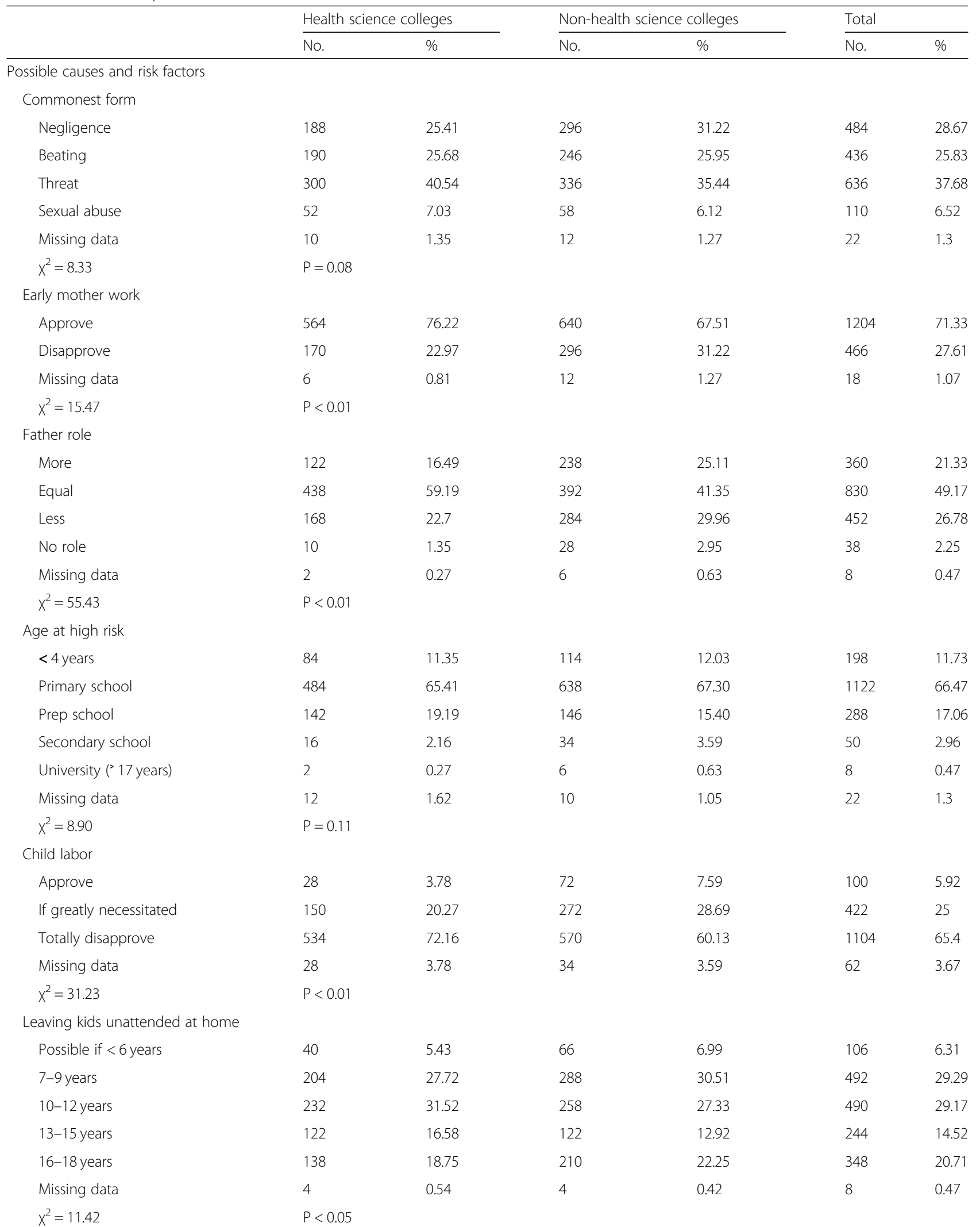


Table 4 Students' opinions and attitudes (Continued)

\begin{tabular}{|c|c|c|c|c|c|c|}
\hline & \multicolumn{2}{|c|}{ Health science colleges } & \multicolumn{2}{|c|}{ Non-health science colleges } & \multicolumn{2}{|l|}{ Total } \\
\hline & No. & $\%$ & No. & $\%$ & No. & $\%$ \\
\hline \multicolumn{7}{|c|}{ Student's awareness about the problem of child sexual abuse } \\
\hline \multicolumn{7}{|l|}{ Problem size } \\
\hline Not a problem & 32 & 4.32 & 24 & 2.53 & 56 & 3.32 \\
\hline Small problem & 320 & 43.24 & 150 & 15.82 & 470 & 27.84 \\
\hline Large problem & 382 & 51.62 & 772 & 81.43 & 1154 & 68.36 \\
\hline Missing data & 6 & 0.81 & 2 & 0.21 & 8 & 0.47 \\
\hline$x^{2}=173$ & $P<0$ & & & & & \\
\hline \multicolumn{7}{|l|}{ Age at the greatest risk } \\
\hline$<4$ years & 80 & 10.81 & 80 & 8.44 & 160 & 9.48 \\
\hline Primary school & 280 & 37.84 & 264 & 27.85 & 544 & 32.23 \\
\hline Prep school & 158 & 21.35 & 160 & 16.88 & 318 & 18.84 \\
\hline Secondary school & 138 & 18.65 & 238 & 25.11 & 376 & 22.27 \\
\hline University & 66 & 8.92 & 168 & 17.72 & 234 & 13.86 \\
\hline Missing data & 18 & 2.43 & 38 & 4.01 & 56 & 3.32 \\
\hline$x^{2}=53.87$ & $P<0$ & & & & & \\
\hline \multicolumn{7}{|l|}{ Sexual abusers } \\
\hline Family & 118 & 15.95 & 176 & 18.57 & 294 & 17.42 \\
\hline Friends & 214 & 28.92 & 276 & 29.11 & 490 & 29.03 \\
\hline Strangers & 382 & 51.62 & 464 & 48.95 & 846 & 50.12 \\
\hline Missing data & 26 & 3.51 & 32 & 3.38 & 58 & 3.44 \\
\hline$x^{2}=2.26$ & $P=0$ & & & & & \\
\hline \multicolumn{7}{|l|}{ Sexual education } \\
\hline Primary stage & 176 & 23.78 & 338 & 35.62 & 514 & 30.45 \\
\hline Prep or secondary & 380 & 51.35 & 324 & 34.18 & 704 & 41.71 \\
\hline Only campaigns & 166 & 22.43 & 248 & 26.16 & 414 & 24.53 \\
\hline Not important at all & 12 & 1.62 & 28 & 2.95 & 40 & 2.37 \\
\hline Missing data & 6 & 0.81 & 10 & 1.05 & 16 & 0.95 \\
\hline$x^{2}=54.35$ & $\mathrm{P}<0$ & & & & & \\
\hline
\end{tabular}

Students awareness about abuse complications and control

Corporal punishment

Completely allowed

Allowed within limits

Not allowed at all

Missing data

$x^{2}=8$

The most dangerous complication

Psychological problems

Personality changes

Study stumbling

Drugs addiction

Missing data

$x^{2}=9.85$

\section{6}

558

144

2

$P<0.05$
$4.86 \quad 26$

$75.41 \quad 700$

19.46

0.27

54.32

33.51

5.68

3.51

2.97

$P<0.05$
402

42

26

22 
Table 4 Students' opinions and attitudes (Continued)

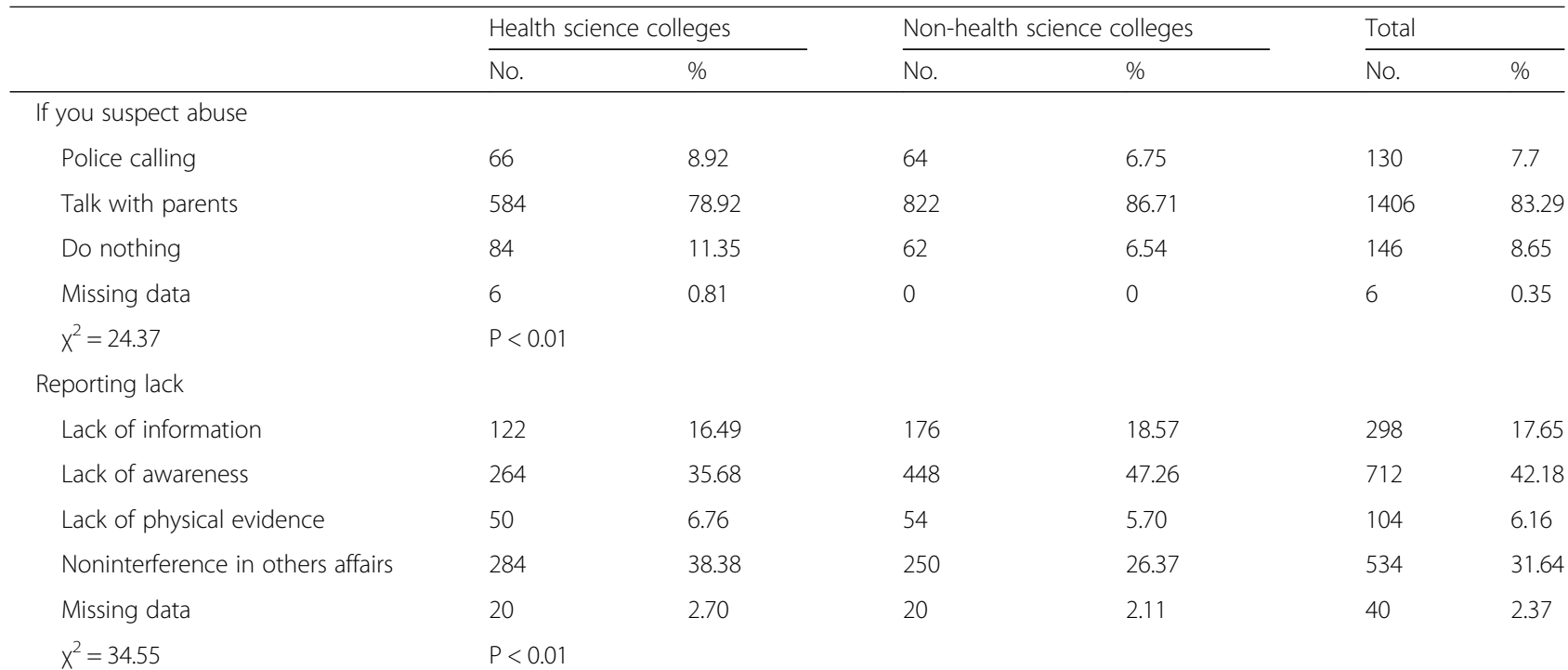

Students' opinions about FGM

Approval of FGM

Approve
Disapprove
Do not know
Missing data
$X^{2}=14.35$
Origin

Religious cause

Social custom

Do not know

$X^{2}=5.08 P=0.08$

Aim

Ethical

Hygiene

Early puberty

Do not know

$x^{2}=65.65$

FGM risks

Highly dangerous

Moderately dangerous

Low dangerous

Non dangerous

Do not know

$x^{2}=64.88$

Legal punishment

\section{Approve}

Disapprove

Do not know

$x^{2}=15.56$
88

426

226

0

$P<0.01$
144

578

18

478

158

56

48

$P<0.01$
11.89

57.57

30.54

0

19.46

78.11

2.43

64.59

21.35

7.57

6.49

29.73

39.46

16.76

7.03

7.03

52

$P<0.01$

402

312

26

$P<0.01$
54.32

42.16

3.51
164

486

294

4

178

760

10

456

322

134

36

388

276

132

128

24

512

428

8
17.30

51.27

31.01

0.42

18.78

80.17

1.05

48.10

33.97

14.14

3.80

40.93

29.11

13.92

13.50

2.53

54.01

45.15

0.84
252

912

520

4

322

1338

28

934

480

190

84

4.98

14.93

54.03

30.81

0.24

79.27

1.66

28.44

11.26
19.08

5.33

36.02

33.65

15.16

10.66

$\begin{array}{ll}76 & 4.5\end{array}$

54.15

43.84

2.01 
Table 4 Students' opinions and attitudes (Continued)

\begin{tabular}{|c|c|c|c|c|c|c|}
\hline & \multicolumn{2}{|c|}{ Health science colleges } & \multicolumn{2}{|c|}{ Non-health science colleges } & \multicolumn{2}{|c|}{ Total } \\
\hline & No. & $\%$ & No. & $\%$ & No. & $\%$ \\
\hline \multicolumn{7}{|c|}{ Pregnancy affection } \\
\hline Yes & 190 & 25.68 & 254 & 26.79 & 444 & 26.3 \\
\hline No & 180 & 24.32 & 270 & 28.48 & 450 & 26.66 \\
\hline Maybe & 350 & 47.30 & 418 & 44.09 & 768 & 45.5 \\
\hline Missing data & 20 & 2.7 & 6 & 0.63 & 26 & 1.54 \\
\hline$x^{2}=15.39$ & \multicolumn{6}{|c|}{$P<0.05$} \\
\hline
\end{tabular}

Regarding the origin of FGM and why it is commonly practiced, most of the students thought it is a social custom and only $19 \%$ said that it has religious causes. More than half of the students perceived that FGM is carried out for ethical causes (traditional for fear of misconduct), $28 \%$ said that it is done for self-hygiene and cleanliness, $11 \%$ thought that it is done for early puberty which is a common but incorrect perception in the society, and about $5 \%$ had no idea. Most of the students saw that FGM is dangerous to women's life, but only one quarter of them thought that FGM can negatively affect female fertility. More than half of the students approved the legal punishment of FGM performers by the court. The difference in believes and opinions between the two groups was also significant regarding FGM's aim, risks, effect on pregnancy, and legal punishment (Table 4).

Moreover, Chi square analysis showed that FGM approval was related to non-health science colleges, male sex, rural residence, and low parents' level of education. Approval was not related to the academic year or exposure to abuse (Table 5).

Simple logistic regression analysis revealed the following predictive factors for FGM approval: non-health science colleges $(\mathrm{OR}=1.56,95 \% \mathrm{CI}=1.05-2.31)$, male sex $(\mathrm{OR}=2.08,95 \% \mathrm{CI}=1.41-3.06)$, rural residence $(\mathrm{OR}=$ 3.2, $95 \% \mathrm{CI}=2.03-5.04)$, fathers' elementary level of education $(\mathrm{OR}=2.2,95 \% \mathrm{CI}=1.31-3.68)$, and mothers' elementary $(\mathrm{OR}=3.22,95 \% \mathrm{CI}=1.89-5.47)$ and high levels of education $(\mathrm{OR}=2.07,95 \% \mathrm{CI}=1.21-3.54)$ (Table 6).

Further analysis using multiple (Table 6) and multiple stepwise (Table 7) logistic regression indicated that the strongest predictive factors for FGM approval are rural residence $(\mathrm{AOR}=4.07,95 \% \mathrm{CI}=2.4-6.9)$ and combined the male sex $(\mathrm{AOR}=2.14,95 \% \mathrm{CI}=1.36-3.37)$ and rural residence $(\mathrm{AOR}=4.49,95 \% \mathrm{CI}=2.63-7.67)$.

\section{Discussion}

In the past, children were considered to be the possession of their parents who were able to treat them as they wanted. There are incidents of various types of child abuse and infanticide in early history where children could be killed sold into slavery or abandoned. Today, violence against children is fairly common in different countries (Ten Bensel et al. 1997). Yet, there is debate over the exact features of maltreatment due to many different definitions of child abuse. But in fact, individual mores and cultural variations form how each person realize child abuse. Because of social refusal, maltreatment acts are concealed from public judgment and the actual prevalence of child abuse stays mainly unknown. Traditional attitudes which are ordinary for one culture can seem abusive to others unfamiliar with these cultural behaviors, such as African traditions involving marriages, gender inequity, and education may seem hurtful to Westerners. Also, isolation of the children to sleep in a separate darkroom is considered a harsh behavior by non-Western cultures.

Our study showed that health science college students were more life satisfied and felt loved more than nonhealth science college students despite near percentages of both groups in experiencing child abuse and exposure to injuries. Health science colleges are more desired by society and accept the students with higher grades so this success can be the cause of more life satisfaction in this group of students. Males and first academic year students were more exposed to physical child abuse. But physical abuse was not related to faculty, residence, parents' education level, or family condition indicating that physical punishment is commonly practiced and socially accepted. Aberle et al. (2007) in their study on first and fourth grade high school students in Slavonski Brod, Croatia, stated that the fourth grade students were unsatisfied and felt unloved more than those of first grade, about $80 \%$ of the students were abused and physical abuse was more significantly common in first grade students also. A US study performed on 1000 adults of both men and women showed that about one third of the females were exposed to child abuse and a higher percentage of about $40 \%$ was in males. Physical abuse was reported by $19 \%$ and sexual abuse by $5 \%$ (Scher et al. 2004). Another study in Thailand performed on elementary school pupils showed that $95 \%$ of sixth-grade pupils experienced emotional abuse and 77\% experienced 
Table 5 Relation between female genital mutilation approval and various qualitative data (Chi square test)

\begin{tabular}{|c|c|c|c|c|}
\hline & \multicolumn{2}{|l|}{ FGM } & \multirow[t]{2}{*}{ Total } & \multirow[t]{2}{*}{$P$ value } \\
\hline & Do not know or disapprove & Approve & & \\
\hline \multicolumn{5}{|c|}{ Type of college } \\
\hline Health science colleges & $652(88.1 \%)$ & 88 (11.9\%) & 740 & 0.027 \\
\hline Non-health science & $780(82.6 \%)$ & $164(17.4 \%)$ & 944 & \\
\hline \multicolumn{5}{|c|}{ Academic year } \\
\hline 1 & $476(85.3 \%)$ & $82(14.7 \%)$ & 558 & 0.633 \\
\hline 2 & $294(84 \%)$ & $56(16 \%)$ & 350 & \\
\hline 3 & $374(82.7 \%)$ & $78(17.3 \%)$ & 452 & \\
\hline 4 & $202(88.6 \%)$ & $26(11.4 \%)$ & 228 & \\
\hline 5 & $36(85.7 \%)$ & $6(14.3 \%)$ & 42 & \\
\hline 6 & $14(100 \%)$ & $0(0 \%)$ & 14 & \\
\hline \multicolumn{5}{|c|}{ Sex } \\
\hline Male & $502(79.2 \%)$ & $132(20.8 \%)$ & 634 & $<0.001$ \\
\hline Female & $902(88.8 \%)$ & $114(11.2 \%)$ & 1016 & \\
\hline \multicolumn{5}{|c|}{ Residence } \\
\hline Rural & $696(79.3 \%)$ & $182(20.7 \%)$ & 878 & $<0.001$ \\
\hline Urban & $660(92.4 \%)$ & $54(7.6 \%)$ & 714 & \\
\hline \multicolumn{5}{|c|}{ Father education } \\
\hline Elementary school & $200(76.9 \%)$ & $60(23.1 \%)$ & 260 & 0.010 \\
\hline High school & $494(84.6 \%)$ & $90(15.4 \%)$ & 584 & \\
\hline College & $644(88 \%)$ & $88(12 \%)$ & 732 & \\
\hline \multicolumn{5}{|c|}{ Mother education } \\
\hline Elementary school & $324(77.9 \%)$ & $92(22.1 \%)$ & 416 & $<0.001$ \\
\hline High school & $438(84.6 \%)$ & 80 (15.4\%) & 518 & \\
\hline College & 544 (91.9\%) & $48(8.1 \%)$ & 592 & \\
\hline \multicolumn{5}{|c|}{ Abuse exposure } \\
\hline Infrequent & $990(85.8 \%)$ & 164 (14.2\%) & 1154 & 0.310 \\
\hline Frequent & $432(83.1 \%)$ & 88 (16.9\%) & 520 & \\
\hline
\end{tabular}

physical punishment (Isaranurug et al. 2002). Male children are more active and thus can be more exposed to corporal punishment.

In our study, the commonest types of child abuse was thought to be verbal or emotional abuse followed by negligence then physical abuse and finally sexual abuse. The age at the greatest risk for abuse was proposed to be that of primary school. This period in children's life is full of naughtiness and misbehavior but unfortunately, it also has a great effect on child personality and shaping. It is stated by the US Department of Health and Human Services that there were 12.3/1000 children exposed to child abuse for the year 2000. The main forms of abuse were neglect (60\%), physical punishment $(20 \%)$, sexual harassment (10\%), and psychological abuse (7\%). The age at the greatest risk for abuse was up to 3 years old, girls were more exposed than boys, and the abusers were mainly parents in about $80 \%$ (Leicht and Madigan 2004). The age at the greatest risk for abuse was stated by Stanić (2006) to be 4-8 years. Most parents would use verbal punishment as yelling or threatening their children before physical punishment, so this form of abuse can be more common. Also, the age of 4 years can be the most exposed to abuse as the children at this age start to understand others and express themselves. 
Table 6 Logistic regression analysis of predictive factors for FGM approval

\begin{tabular}{|c|c|c|c|}
\hline & OR & $95 \% \mathrm{Cl}$ & $P$ value \\
\hline \multicolumn{4}{|c|}{ Simple logistic regression analysis } \\
\hline \multicolumn{4}{|l|}{ Type of college } \\
\hline Health science colleges & Ref. & & \\
\hline Non-health science & 1.56 & $1.05-2.31$ & 0.028 \\
\hline \multicolumn{4}{|l|}{ Sex } \\
\hline Female & Ref. & & \\
\hline Male & 2.08 & $1.41-3.06$ & $<0.001$ \\
\hline \multicolumn{4}{|l|}{ Residence } \\
\hline Urban & Ref. & & $<0.001$ \\
\hline Rural & 3.2 & $2.03-5.04$ & \\
\hline \multicolumn{4}{|l|}{ Father education } \\
\hline College & Ref. & & \\
\hline High school & 1.33 & $0.85-2.09$ & 0.208 \\
\hline Elementary school & 2.2 & $1.31-3.68$ & 0.003 \\
\hline \multicolumn{4}{|l|}{ Mother education } \\
\hline College & Ref. & & \\
\hline High school & 2.07 & $1.21-3.54$ & 0.008 \\
\hline Elementary school & 3.22 & $1.89-5.47$ & $<0.001$ \\
\hline \multicolumn{4}{|c|}{ Multiple logistic regression analysis } \\
\hline \multicolumn{4}{|l|}{ Type of college } \\
\hline Health science colleges & Ref. & & \\
\hline Non-health science & 1.28 & $0.75-2.17$ & 0.362 \\
\hline \multicolumn{4}{|l|}{ Sex } \\
\hline Female & Ref. & & \\
\hline Male & 2.44 & $1.52-3.9$ & $<0.001$ \\
\hline \multicolumn{4}{|l|}{ Residence } \\
\hline Urban & Ref. & & \\
\hline Rural & 3.45 & $1.9-6.24$ & $<0.001$ \\
\hline \multicolumn{4}{|l|}{ Father education } \\
\hline College & Ref. & & \\
\hline High school & 0.65 & $0.35-1.2$ & 0.167 \\
\hline Elementary school & 0.85 & $0.38-1.9$ & 0.688 \\
\hline \multicolumn{4}{|l|}{ Mother education } \\
\hline College & Ref. & & \\
\hline High school & 2.07 & $1.01-4.23$ & 0.047 \\
\hline Elementary school & 2.17 & $0.92-5.13$ & 0.076 \\
\hline
\end{tabular}

Most of the students in this study approved the idea of mothers having jobs outside home before their children reach the age of school enrollment and about half of them saw that the father's role in rearing children is equal to the mother's. Moreover, two thirds of the students stated that the most suitable age that children become dependent and their mothers can leave them
Table 7 Multiple stepwise logistic regression analysis of predictive factors for FGM approval

\begin{tabular}{lllll}
\hline Model & & AOR & $95 \% \mathrm{Cl}$ & $P$ value \\
\hline 1 & Residence & & & \\
Urban & Ref. & & $<0.001$ \\
Rural & 4.07 & $2.4-6.9$ & \\
2 & Sex & & & $<0.001$ \\
& Female & Ref. & & \\
Male & 2.14 & $1.36-3.37$ & \\
& Residence & & & $<0.001$ \\
\hline & Urban & Ref. & & \\
& Rural & 4.49 & $2.63-7.67$ & \\
& & & & \\
\hline
\end{tabular}

unattended at home for a few hours is $7-15$ years and about $65 \%$ completely disapproved child labor.

In accordance with our results, Rathge et al. (2005) stated that about half the respondents saw that child abuse is a moderate problem. The ages of $0-4$ and $5-8$ were equally exposed to physical child abuse (35.8 and 36.6\%). $57.1 \%$ of participating households chose the age of 12-14 years that the mother can leave her children alone at home. Family awareness of sound methods for adjusting the children's behavior seems to vary among different populations, cultures, and socioeconomic levels. But early years of the child's life have shown to be the most vulnerable age.

In this study, about $68 \%$ of the students stated that sexual abuse is a widespread phenomenon in the society. About one third of them saw that the age at the greatest risk for sexual abuse was also proposed to be the primary school age and about half of them saw that the abusers are mainly strangers. Sexual education was thought to be important in the prep or secondary school age in $42 \%$ of the students while one third of the students supported its importance earlier in the primary school age. In another study, Whealin (2016) stated that about $20 \%$ of women and $10 \%$ of men were previously exposed to sexual abuse during their childhood and that the abuser was a minor in one third of the cases. The abusers were family members (30\%), friends and acquaintances (60\%), and strangers (only 10\%).

The fact that sexual abusers are mainly family or friends who are, in most cases, familiar to the child should be explained to the society as a large percentage of students in our study did not expect such probability.

In our study, most of the students approved child corporal punishment despite that half of them stated the most dangerous child abuse complication to be psychological problems (e.g. depression). Most of the students (42.18\%) thought that the reason for lack of reporting the abuse is lack of awareness. Moreover, most of them would advise the child's parents if they suspect a case of 
abuse while the least percentage would call the police. In agreement with these results, Rathge et al. (2005) also found that a percentage of $74.6 \%$ disapproved child corporal punishment and that the majority of the participants perceived violence to be the most dangerous child abuse complication followed by depression. Two thirds of the participants would call the police for a case of child abuse and only one fifth of them would advise the parents. $62.7 \%$ said that the lack of information about how to report abuse and follow up the situation causes people to hesitate to report.

There is an obvious cultural difference in attitudes toward children raising and parenting. Shanalingigwa (2009) in their study showed that African parents viewed sexual abuse, illicit drugs and alcohol abuse, and health neglect more severe than did the US parents but they showed less perception of corporal punishment as physical abuse. Most African and Asian parents thought that corporal punishment is the most effective way to ensure children's obedience starting from the age of 4-5 years and physical punishment is not banned in most of the schools. But Western parents showed less tolerance for physical abuse. American schools also have precise policies against sexual abuse and bullying and are concerned in teaching children to recognize unsuitable behaviors. There were common agreements between cultures of the West and Africa. Both of them ranked sexual abuse to be the most serious type of abuse and evaluated housing, educational, and clothing neglect to be the least serious types.

Regarding FGM, the Egyptian Health Issues Survey (2015) indicated that $87 \%$ of Egyptian women were subjected to FGM. However, the rate of practice among younger women declined. Our study showed that only half of the students disapproved FGM and one third of them had no idea. The strongest predictive factors for FGM approval were rural residence and male sex. More than half of them approved legal punishment of FGM performers by the court and this percentage can reflect the real disapproval as the percent of students who could not completely disapprove FGM and chose to have no idea is high (one third). FGM approval is still high and this supports the fact that FGM is commonly practiced in Egypt.

About $10 \%$ of the students stated that FGM is not dangerous to women's life and about half of them did not know that FGM could affect female fertility. Despite the statistically significant difference between the health science colleges and the non-health science colleges groups, the percentages were close indicating a lack of awareness even in the biology study-specialized group (health science colleges group).

More than three fourths of the students saw it is a social custom (not religious) and more than half of them saw it is performed for ethical causes. So we can conclude that education and awareness campaigns can greatly help to diminish this injurious habit.

But Mohammed et al. (2016) in their work on an Egyptian village showed that FGM was more supported by females despite that females had a better level of knowledge about FGM health risks. This difference may be because females in rural areas are more influenced by the traditions that encourage gender inequity between men and women. But in their study, males were more encouraging the opinion that husbands prefer their wives to be performed FGM. This supports our vision about the importance of men's contribution to FGM prevention.

There are some other African studies about FGM. A Nigerian study by Ezenyeaku et al. (2011) showed that $42.1 \%$ of women had FGM and only $14.3 \%$ approved FGM for their daughters. FGM aimed to prevent promiscuity in $38.3 \%$, about one quarter of them chose culture, another one quarter chose no reason, and other causes were hygiene, religion, and aid future childbirth. The commonest injurious aftereffects were proposed to be sexual problems, psychological problems as feeling incompleteness, and obstetric problems. $4.8 \%$ of women indicated that FGM is safe. Only $63.7 \%$ of them approved the legal prevention of FGM.

Moreover, Abubakar et al. (2004), in another Nigerian study, stated that $25.7 \%$ of the participants indicated sexual problems as the commonest FGM complications and $8.6 \%$ of them indicated obstetric problems.

The geographic distribution of FGM among different societies in Africa indicates that FGM is a social custom with no religious causes as it is practiced in different countries and tribes with different religious beliefs sharing the same habit.

\section{Conclusion}

A significant proportion of the students experienced previous physical child abuse which left no injuries in most cases (more in males and first grade students). Also, most of the students propose that child corporal punishment can be allowed despite that about half of them see that the most dangerous aftereffect of child abuse was psychological problems. Deficient reporting of this problem is mainly explained to be due to a lack of awareness. A significant lack of awareness about FGM complications is observed in both groups (health science and non-health science colleges) and the opinions are very close. It is obvious that FGM is more approved and supported by rural men particularly.

\section{Study limitations}

Firstly, data are self-reported so socially desirable answers may be given as it is obvious in answering the 
question about domestic life satisfaction. Secondly, the study focuses on physical child abuse exposure and stresses on left injuries to evaluate its seriousness but a sensitive issue like sexual abuse is not assessed as these questions can be unpleasant and not socially accepted by the students. Moreover, prevalence of neglect and psychological abuse are not assessed. Despite being more common than physical abuse, these forms of abuse have no obvious culturally accepted definitions and are difficult to assess their seriousness. Thirdly, despite a high response rate, there were some objections to the questionnaire. Mainly, it was long and some answers were not included in the appointed choices (as the noneducation choice in the questions of father and mother education). Longitudinal studies should be performed to assess the causality between child abuse exposure and health risk behaviors as an outcome.

\section{Recommendations}

Awareness campaigns against child abuse and female genital mutilation should be held for children, parents, and university students who are the parents of the early future. There is an obvious problem of lack of awareness especially in rural resident students. Men should be included and targeted for more serious outreach. Premarriage parents' education classes and home visitations to provide social and educational support can also prevent child abuse.

\section{Supplementary information}

Supplementary information accompanies this paper at https://doi.org/10 1186/s41935-019-0174-y.

Additional file 1. The questionnaire about child abuse,

\section{Abbreviation}

FGM: Female genital mutilation

\section{Acknowledgements}

The authors would like to thank Professor Dr. Sherien Ghaleb, Faculty of Medicine, Cairo University, for her valuable support and comments during editing this study.

\section{Authors' contributions}

All authors contributed in data collection, data analysis, and manuscript writing. All authors read and approved the final manuscript.

\section{Funding}

No funding sources.

\section{Availability of data and materials}

All data have been presented in the manuscript and there are no additional data.

\section{Ethics approval and consent to participate}

Informed consent was obtained as used data were completely anonymized and students who approved participating in the study answered the questionnaire.

This study was approved by the institutional ethics committee (Faculty of Medicine, Beni Suef University).
Consent for publication

Not applicable as no participants were involved.

\section{Competing interests}

The authors declare that they have no competing interests.

\section{Author details}

${ }^{1}$ Forensic Medicine and Clinical Toxicology Department, Faculty of Medicine, Beni Suef University, Beni Suef, Egypt. 'Pediatric Medicine Department, Faculty of Medicine, Beni Suef University, Beni Suef, Egypt.

Received: 20 March 2019 Accepted: 2 December 2019

Published online: 23 December 2019

\section{References}

Aberle N, Ratković-Blažević V, Mitrović-Dittrich D, Coha R, Stoić A, Bublić J, Boranić M (2007) Emotional and physical abuse in family: survey among high school adolescents. Croat Med J 48:240-248

Abubakar I, lliyasu Z, Kabir M, Uzoho CC, Abdulkadir MB (2004) Niger knowledge, attitude and practice of female genital cutting among antenatal patients in Aminu Kano teaching hospital, Kano. J Med 13(3):254-258

Alexander RC, Levitt CJ, Smith WL (2001) Abusive head trauma. In: Reece RM, Ludwig S (eds) Child abuse: medical diagnosis and management, 2nd edn. Lippincott Williams \& Wilkins, Philadelphia, pp 47-80

Cappa C et al (2013) Female genital mutilation/cutting: a statistical overview and exploration of the dynamics of change. United Nations Children's Fund, New York, pp 30-48

Egyptian Health Issues Survey (2015) Ministry of Health and Population [Egypt], El-Zanaty and Associates [Egypt], and ICF International. Ministry of Health and Population and ICF International, Cairo and Rockville https://dhsprogram.com/publications/publication-FR313-DHS-Final-Reports. cfm. Accessed 3 Nov 2016

Elsaied HF, Alsehly AA (2017) A study of child physical abuse. Egypt J Psychiatry 38:120-126

Ezenyeaku CC, Okeke TC, Chigbu CO, Ikeako LC (2011) Survey of women's opinions on Female Genital Mutilation (FGM) in Southeast Nigeria: study of patients attending antenatal clinic. Ann Med Health Sci Res 1(1):15-20

Golden JA, Prather W (2009) A behavioral perspective of childhood trauma and attachment issues: toward alternative treatment approaches for children with a history of abuse. Int J Behav Consult Ther 5:56-74

Hahm H, Guterman N (2001) The emerging problem of physical child abuse in South Korea. Child Maltreat 6:169-179

Isaranurug S, Chansatitporn N, Auewattana P, Wongarsa C (2002) Violence against children by parents. J Med Assoc Thai 85:875-880

Kelly-Irving M, Lepage B, Dedieu D, Bartley M, Blane D, Grosclaude P et al (2013) Adverse childhood experiences and premature all-cause mortality. Eur J Epidemiol 28:721-734

Leicht T, Madigan H (2004) Child maltreatment: summary of key findings. Child Welfare Information Gateway http://www.childwelfare.gov/pubs/factsheets/ canstats.cfm. Accessed 16 Nov 2006

Michael M (2007) Egypt officials ban female circumcision. The Associated Press. Available from: http://www.phys.org/news102393179. Accessed 13 July 2016

Mohammed ES, Seedhom AE, Mahfouz EM (2016) Female genital mutilation: current awareness, believes and future intention in rural Egypt. Reprod Health 15(1):175. https://doi.org/10.1186/s12978-018-0625-1

Morad Y, Wygnansky-Jaffe T, Levin AV (2010) Retinal haemorrhage in abusive head trauma. Clin Exp Ophthalmol 38(5):514-520

Rasheed SM, Abd-Ellah AH, Yousef FM (2011) Female genital mutilation in Upper Egypt in the new millennium. Int J Gynaecol Obstet 114(1):47-50

Rathge R, Nikle J, Danielson R, Schwarzwalter K (2005) North Dakota Statewide Child Abuse and Neglect Study: Survey Results. North Dakota State Data Center http://www.ndsu.edu/sdc/publications.htm

Reisel D, Creighton SM (2015) Long term health consequences of female genital mutilation (FGM). Maturitas 80(1):48-51

Scher CD, Forde DR, McQuaid JR, Stein MB (2004) Prevalence and demographic correlates of childhood maltreatment in an adult community sample. Child Abuse Negl 28:167-180

Shanalingigwa, Oswald Abel (2009). Understanding social and cultural differences in perceiving child maltreatment. Retrieved from the University of Minnesota Digital Conservancy http://hdl.handle.net/11299/54824 
Stanić I. (2006). Violence and child abuse [in Croatian], Narodni zdravstveni list, Available at: http://www.zzizpgz.hr/nzl/5/zlostavljanje.htm

Straus MA, Gelles RJ (1998) Identification of child maltreatment with the parentchild conflict tactics scales: development and psychometric data for a national sample of American parents. Child Abuse Negl 22:249-270

Ten Bensel RW, Rheinberger MM, Radbill SX (1997) Children in a world of violence the roots of child maltreatment. In: Helfer ME, Kempe RS, Krugman RD (eds) The battered child. University of Chicago Press, Chicago

Theoklitou D, Kabitsis N, Kabitsi A (2012) Physical and emotional abuse of primary school children by teachers. Child Abuse Negl 36(1):64-70

Whealin J (2016) Child sexual abuse. National Center for Post Traumatic Stress Disorder, US Department of Veterans Affairs

WHO (1999) Report of the consultation on child abuse prevention, world health organization, Geneva, pp 13-16 (document WHO/HSC/PVI/99.1)

Youssef RM, Attia MS, Kamel MI (1998) Children experiencing violence: parental use of corporal punishment. Child Abuse Negl 22:959-973

\section{Publisher's Note}

Springer Nature remains neutral with regard to jurisdictional claims in published maps and institutional affiliations.

\section{Submit your manuscript to a SpringerOpen ${ }^{\circ}$ journal and benefit from:}

- Convenient online submission

- Rigorous peer review

- Open access: articles freely available online

High visibility within the field

- Retaining the copyright to your article 